\title{
EGFR Antibody
}

National Cancer Institute

\section{Source}

National Cancer Institute. EGFR Antibody. NCI Thesaurus. Code C122777.

Any immunog lobulin that recognizes epidermal growth factor receptor protein. 